\title{
THE ASSOCIATION OF CATECHOL-O-METHYL-TRANSFERASE AND INTERLEUKIN 6 GENE POLYMORPHISMS WITH POSTTRAUMATIC STRESS DISORDER
}

\author{
Valdete Haxhibeqiri ${ }^{1}$, Shpend Haxhibeqiri ${ }^{2}$, Valdete Topciu-Shufta ${ }^{1,3}$, Ferid Agani ${ }^{3}$, \\ Aferdita Goci Uka ${ }^{4}$, Blerina Hoxha ${ }^{4}$, Alma Dzubur Kulenovic ${ }^{5}$, Miro Jakovljević ${ }^{6}$, \\ Esmina Avdibegović ${ }^{7,8}$, Nermina Kravić ${ }^{7,8}$, Mirnesa Muminović Umihanić ${ }^{9}$, Osman Sinanović ${ }^{8}$, \\ Emina Šabić Džananović ${ }^{5}$, Abdulah Kučukalić ${ }^{5}$, Sabina Kučukalić ${ }^{5}$, Alma Bravo Mehmedbašićć, \\ Branka Aukst Margetić ${ }^{10}$, Nenad Jakšićc ${ }^{6}$, Ana Cima Franc ${ }^{6}$, Duško Rudan ${ }^{6}$, Marko Pavlovićcí, \\ Romana Babić $^{11}$, Elma Ferić Bojić ${ }^{12}$, Damir Marjanović ${ }^{13}$, Nada Božina ${ }^{14}$, Christiane Ziegler ${ }^{14}$, \\ Christiane Wolf $^{14}$, Bodo Warrings ${ }^{15}$, Katharina Domschke ${ }^{15}$, Jürgen Deckert ${ }^{14}$ \& Dragan Babić ${ }^{11}$ \\ ${ }^{I}$ Department of Clinical Biochemistry, University Clinical Centre of Kosovo, Prishtina, Kosovo \\ ${ }^{2}$ Institute of Kosovo Forensic Psychiatry, University Clinical Center of Kosovo, Prishtina, Kosovo \\ ${ }^{3}$ Faculty of Medicine, University Hasan Prishtina, Prishtina, Kosovo \\ ${ }^{4}$ Department of Psychiatry, University Clinical Centre of Kosovo, Prishtina, Kosovo \\ ${ }^{5}$ Department of Psychiatry, Clinical Centre University of Sarajevo, Bosnia and Herzegovina \\ ${ }^{6}$ Department of Psychiatry, University Hospital Center Zagreb, Zagreb, Croatia \\ ${ }^{7}$ Department of Psychiatry University Clinical Centre Tuzla, Tuzla, Bosnia and Herzegovina \\ ${ }^{8}$ School of Medicine, University of Tuzla, Tuzla, Bosnia and Herzegovina \\ ${ }^{9}$ Community Health Centre Živinice, Živinice, Bosnia and Herzegovina \\ ${ }^{10}$ Department of Psychiatry, University Hospital Centre Sestre Milosrdnice, Zagreb, Croatia \\ ${ }^{11}$ Department of Psychiatry, University Clinical Center of Mostar, Mostar, Bosnia and Herzegovina \\ ${ }^{12}$ Department of Genetics and Bioengeneering, International Burch University, Sarajevo, Bosnia and Herzegovina \\ ${ }^{13}$ Department of Laboratory Diagnostics, University Hospital Center Zagreb, Zagreb, Croatia \\ ${ }^{14}$ Department of Psychiatry, Psychosomatics and Psychotherapy, Center of Mental Health, \\ University Hospital of Würzburg, Würzburg, Germany \\ ${ }^{15}$ Department of Psychiatry and Psychotherapy, Medical Center - University of Freiburg, \\ Faculty of Medicine, University of Freiburg, Freiburg, Germany
}

received: 4.2.2019;

revised: 14.5.2019;

accepted: 22.5.2019

\section{SUMMARY}

Background: Posttraumatic stress disorder (PTSD) is a disorder that occurs in some people who have experienced a severe traumatic event. Several genetic studies suggest that gene encoding proteins of catechol-O-methyl-transferase (COMT) may be relevant for the pathogenesis of PTSD. Some researchers suggested that the elevation of interleukin-6 (IL6) correlates with major depression and PTSD. The aim of this study was to investigate whether the single nucleotide polymorphisms COMT rs4680 (Val158Met) and IL6 rs 1800795 are associated with PTSD and contribute to the severity of PTSD symptoms.

Subjects and methods: This study comprised 747 participants that experienced war between 1991 and 1999 in the South Eastern Europe conflicts. COMT rs4680 (Val158Met) and IL6 rs 1800795 genotypes were determined in 719 participants (369 with and 350 without PTSD). The Mini International Neuropsychiatric Interview (M.I.N.I.), the Clinician Administrated PTSD Scale (CAPS) questionnaire and the Brief Symptom Inventory (BSI) were used for data collection.

Results: Regarding the COMT gene polymorphism, the results of the regression analyses for BSI total score were significant in the lifetime PTSD group in the dominant $(P=0.031)$ and the additive allelic model $(P=0.047)$. Regarding the IL6 gene, a significant difference was found for the recessive model predicting CAPS total score in the lifetime PTSD group (P=0.048), and indicated an association between the $C$ allele and higher CAPS scores. $n$ the allelic, genotypic and rezessive model, the results for BSI total score were significant in the lifetime PTSD group $(P=0.033, P=0.028$ and $P=0.009)$, suggesting a correlation of the $C$ allele with higher BSI scores

Conclusion: Although our nominally significant results did not withstand correction for multiple tests they may support a relevance of the COMT (Val158Met) and IL6 rs1800795 polymorphism for aspects of PTSD in war traumatized individuals.

Key words: war trauma - PTSD - COMT - IL6 - gene polymorphism

\section{INTRODUCTION}

Posttraumatic stress disorder (PTSD) is a consequence of severe traumatic experiences such as torture, war, and genocide (American Psychiatric Association
2000). PTSD etiology is considered to be multifactorial with an interaction of environmental traumatic factors and genetic factors (Agani et al. 2010). Epidemiological studies worldwide have documented a high rate of traumatic events including life-threatening accidents, rape, 
combat, physical violence, witnessing the death or injury of others and natural disasters (Gillespie et al. 2009). In their study, Neuner et al. (2004) reported that prevalence rates of PTSD in survivors of civil war was $30-40 \%$, and in further studies it is estimated to be around $35 \%$, in people who experienced the war in Bosnia and Herzegovina and $25 \%$ in people who experienced the war in Kosovo (Priebe et al. 2010, Lopes et al. 2003). There are individual differences regarding the ability to cope with excessive stress. Therefore, while some people exposed to traumatic events do not develop PTSD, others do develop PTSD symptoms. Twin studies have shown that the development of PTSD following a trauma has a heritability of up to $30-40 \%$. Several genetic components for PTSD have been proposed, including biologic pathways involving the hypothalamic-pituitary-adrenocortical axis (HPAA), the locus coeruleus/noradrenergic system, and the limbic systems (Broekman et al. 2007, Koenen 2007). Interestingly, a method using a cumulative risk score showed that carriers of four or more risk alleles of the candidate genes FK506 - binding protein 5 (FKBP5) (rs9470080), catechol-Omethyltransferase (COMT) (rs4680), and cholinergic receptor nicotinic alpha-5 (CHRNA5; rs16969968) conferred around 7 times the risk of PTSD (Boscarino et al. 2011). COMT is an enzyme that plays a key role in inactivating catecholamine neurotransmitters (dopamine, epinephrine, norepinephrine), their metabolites, catechol estrogens and catechol drugs via methylation. In humans, the gene coding for COMT is located on 22q11.21 (Grossman et al. 1992). The rs4680 functional variant (Val158Met polymorphism) of the COMT gene is the most widely studied COMT single nucleotide polymorphism (SNP), and because of its role in catecholamine regulation, it has garnered great interest from researchers studying psychiatric conditions ranging from PTSD (Kolassa et al. 2010) to obsessive-compulsive disorder (Pooley et al. 2007) and schizophrenia (Egan et al. 2001). A substitution of valine (Val) by methionine (Met) is associated with lower enzyme activity and a subsequent slower catalysis of catecholamines. The difference in activity between $\mathrm{Val} / \mathrm{Val}$ and Met/Met genotypes is three - to four fold and $\mathrm{Val} / \mathrm{Met}$ genotypes showing an intermediate activity (Malhotra et al. 2002).

Recently it has been verified that Interleukin 6 (IL6) is not involved only in the immune response, but it is also linked to disorders like depression and anxiety. It has an important role also in adult neurogenesis (Deverman \& Patterson 2009). Neurogenesisis altered in some neuropathological situations such as stroke, mechanical damage, status epilepticus and neurodegenerative diseases like Alzheimer and Parkinson. A harmful effect of inflammation has been suggested in all of these diseases (Ekdahl et al. 2003, Quintana et al. 2009, Whitney et al. 2009). The IL6 family of cytokines recruits the glycoprotein gp130 for signaling (Kishimoto et al. 1995). Epinephrine and norepinephrine modulate the release of cytokines through $\alpha$ - and $\beta$-adrenoceptors on immune cells (Hasko \& Szabo 1998). In contrast, acetylcholine inhibits the release of TNF, IL1, IL6 and IL18, from endotoxin-activated human macrophages (Borovikova et al. 2000). Pro-inflammatory cytokines such as TNF, IL1, and IL6 can increase in prolonged stressful situations, such as anxiety disorders. Higher levels of stimulated TNF and IL6 were reported in PTSD patients (Rohleder et al. 2004). In their study, Baker et al. (2001) have pointed out that IL6 is significantly elevated in patients and correlates with major depression and PTSD. IL6 is also related to schizophrenia, poor emotional responsiveness manifested with hallucinations, paranoid and mental deterioration and delusions (Erta, Quiantana \& Hidalgo 2012). SNPs, such as rs1800796, influence IL6 expression (IL6 plasma levels are increasedin G allele carriers). Several studies have shown that depression and PTSD are associated with a smaller volume of the hippocampus, which exhibits a strong sensitivity to stress and the response to cytokines (Kasai et al. 2008, MacQueen \& Frodl 2010). The role of IL6 in these relationships is unclear. Many authors investigated the relationship between inflammatory markers and PTSD and it has been reported that psychological stress in humans is associated with increased secretion of IL6 (Maes et al. 1999, Carpenter et al. 2010). Passos et al. (2015) propose that trauma induces chronic low-grade inflammation.

The aim of this study was to investigate the association of the COMT rs4680 (Val158Met) and the IL6 rs1800796 polymorphism with the development of PTSD and their contribution to symptom severity.

\section{SUBJECTS AND METHODS}

\section{Subjects}

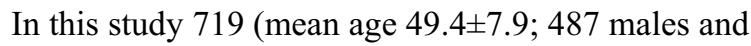
232 females) participants were recruited between 2013 and 2015 at five psychiatric research centers, located in the countries of ex-Yugoslavia, where the population has experienced war-related trauma between 1991 and 1999: Zagreb in Croatia (1991-1992), Sarajevo, Tuzla and Mostar in Bosnia and Herzegovina (1992-1995) and Prishtina in the Republic of Kosovo (1998-1999). The inclusion criteria were that participants should not be younger than 16 years of age at the time of trauma and not older than 65 years of age at time of recruitment. Exclusion criteria were: intellectual disability (MMSE $<25)$, organic and brain trauma related disorders, epilepsy, psychotic disorders, addiction disorders except smoking, oncological illnesses, medication known to affect methylation status, e.g, valproic acid, $1^{\text {st }}$ and $2^{\text {nd }}$ degree relation to an already recruited person. Interviews were performed by medical personnel (psychiatrists, psychologists or psychiatric residents) after trainings. Further details on study design, process of recruitment, assessment instruments, inclusion and exclusion criteria, blood collection and transportation, DNA extraction of SEE PTSD study have been described by Džubur Kulenović et al. (2016). 
For analyses participants were divided into three experimental groups, depending on the presence of PTSD. The first group included 218 patients (mean age $50.1 \pm 6.7$; 157 males and 61 females) who have current PTSD. The second group constitutes of 151 participants (mean age $49.5 \pm 8.2 ; 98$ males and 53 females), who experienced lifetime PTSD, and the third group comprised 350 (mean age $48.8 \pm 8.5 ; 232$ males and 118 females) healthy volunteers who did not develop PTSD.

\section{Ethical Votes}

The study was approved by the local ethics committees. The information and consent form were designed by the Sarajevo center and translated into local language. All participants were informed and gave their written consent according to the principles of the declaration of Helsinki (WMA 2013).

\section{Psychometric Instruments}

Using the Structured Clinical Interview - Mini International Neuropsychiatric Interview (M.I.N.I.) we assessed the presence or absence of PTSD symptoms. To make a categorical PTSD diagnosis and to assess the severity of PTSD symptoms we used the Clinician Administrated PTSD Scale (CAPS) (Blake et al. 1995). And finally Brief Symptom Inventory (BSI) (Derogatis \& Melisaratos 1983) was used for the assessment of psychological symptoms.

\section{Molecular Analyses}

Molecular analysis were performed at the Laboratory of Functional Genomics, Department of Psychiatry, Psychosomatics and Psychotherapy in Würzburg. Genomic DNA was isolated from frozen venous EDTAblood using the FlexiGene DNA Kit (Qiagen, Hilden, Germany) according to manufacturer's instructions and stored until genotyping at $-80^{\circ} \mathrm{C}$.

Genotyping of the COMT rs4680 (Val158Met) SNP was accomplished using standard PCR procedures modified from a previously published protocol (Egan et al. 2001); primers were 5'-GGGGCCTACTGTGGCTACTC3'(forward) and 5'-TTTTTCCAGGTCTGACAACG-3' (reverse). Briefly, PCR reactions were performed in a reaction volume of $25 \mathrm{ml}$, including approximately 45 $65 \mathrm{ng}$ of template genomic DNA, $0.4 \mathrm{mM}$ of each primer, $0.1 \mathrm{mM}$ of each dNTP, $1.5 \mathrm{mM} \mathrm{MgCl} 2,20 \mathrm{mM}$ $\left(\mathrm{NH}_{4}\right)_{2} \mathrm{SO}_{4}, 75 \mathrm{mM}$ Tris- $\mathrm{HCl}$ (pH9), $0.01 \%$ Tween 20 and $0.5 \mathrm{U}$ of Taq DNA polymerase. Cycler conditions were: $5 \mathrm{~min}$ denaturation at $94^{\circ} \mathrm{C}$, followed by 35 cycles with $45 \mathrm{~s}$ at $94^{\circ} \mathrm{C}, 45 \mathrm{~s}$ at $58^{\circ} \mathrm{C}$ and $45 \mathrm{~s}$ at $72^{\circ} \mathrm{C}$ and a final extension step of $5 \mathrm{~min}$ at $72^{\circ} \mathrm{C}$. PCR products were digested with NlaIII $\left(3 \mathrm{~h}\right.$ at $37^{\circ} \mathrm{C}$; fragment sizes: wild-type G1947, 114 bp; 1947A variant, 96 and $13 \mathrm{bp}$ ) and subsequently visualized on a 4\% agarose gel. G1947 corresponds to the highactivity Val158 allele; 1947A codes for the lowactivity Met variant (Ehlis et al. 2007).
The IL6 SNP rs1800795 was genotyped following the described procedure: The respective gene region carrying the rs 1800795 polymorphism was amplified from genomic DNA by PCR with following oligonucleotide primers F: 5'- ACTCAGTTCAGAACATCTTTGGT-3 ‘ and R: 5' - TTCTCTTTCGTTCCCGGTGG-3' in a $25 \mu \mathrm{l}$ reaction volume containing $45-65 \mathrm{ng}$ genomic DNA, $0.4 \mathrm{mM}$ of each primer, $0.1 \mathrm{mM}$ of each nucleotide, $1.5 \mathrm{mM} \mathrm{MgCL}_{2}$ and $0.3 \mathrm{U} \mathrm{Taq}^{\mathrm{TM}}$ DNA polymerase. Cycler conditions were: $5 \mathrm{~min}$ denaturation at $95^{\circ} \mathrm{C}$, followed by 35 cycles with $45 \mathrm{~s}$ at $95^{\circ} \mathrm{C}, 45 \mathrm{~s}$ at $62.5^{\circ} \mathrm{C}$ and $45 \mathrm{~s}$ at $72^{\circ} \mathrm{C}$ and a final extension step of $5 \mathrm{~min}$ at $72^{\circ} \mathrm{C}$. The resulting PCR fragments were digested with the restriction endonuclease SfaNI (NEB, Frankfurt a. Main, Germany) which results in differentially sized fragments representing the respective genotype. The fragments were separated in a $4 \%$ agarose gel by electrophoresis and visualized with ethidium bromide. Fragment lengths and resulting genotypes were determined by two independent investigators blinded for diagnosis.

\section{Statistical analyses}

Statistics were performed using PLINK 1.9. Both of the analyzed SNPs were polymorphous (minor allele frequency $>30 \%$ ), reached a minimal genotyping call rate of $99 \%$ and did not deviate from Hardy-Weinberg equilibrium $(p>0.1)$. Logistic regression was used for case-control analyses. Within the two groups of patients, i.e. individuals with lifetime or current PTSD, linear regression was carried out individually for analyses on CAPS and BSI scores. The following models were tested in all phenotypes: additive allelic, dominant and recessive (all based on the minor allele), as well as the genotypic model. The significance level was Bonferroni adjusted for 23 variants that were analyzed in total within the entire project ( $\alpha=0.002)$ (Džubur Kulenović et al. 2016).

\section{RESULTS}

In order to characterize the role of COMT and IL6 on PTSD, two well investigated SNPs rs4680 and rs1800795 were subject to a case-control analysis in altogether 719 participants. Additonally linear regression analyses were performed with genotypes predicting the total CAPS and BSI scores for current and lifetime PTSD patients separately.

\section{Catechol-o-methyl-transferase (COMT) gene}

Allele and genotype distributions of the COMT polymorphism rs4680 in the PTSD group and controls are shown in Table 1. There was no significant difference between the PTSD group and controls in allele and genotype distributions of the COMT rs4680 variant $\left(\mathrm{P}_{\mathrm{all}}>0.05\right)$. Also no significant difference was found in severity of PTSD symptoms (CAPS total) between allele and genotype groups neither in the lifetime PTSD group nor in patients with current PTSD diagnoses $\left(\mathrm{P}_{\mathrm{all}}>0.05\right)$. 
Table 1. Association results of COMT rs4680, along with genotype- and allele counts, for individuals in analysis, CAPS and BSI means and standard deviations (SD), as well as nominal P-values of regression analyses

\begin{tabular}{|c|c|c|c|c|c|c|c|c|c|}
\hline \multirow{2}{*}{ COMT rs4680 } & \multicolumn{2}{|c|}{ Allelic Model } & \multicolumn{3}{|c|}{ Genotypic Model } & \multicolumn{2}{|c|}{ Dominant Model } & \multicolumn{2}{|c|}{ Recessive Model } \\
\hline & A & G & $\mathrm{AA}$ & $\mathrm{AG}$ & GG & $\mathrm{AA} / \mathrm{AG}$ & GG & AA & $\mathrm{AG} / \mathrm{GG}$ \\
\hline Controls & 344 & 354 & 87 & 170 & 92 & 344 & 354 & 87 & 262 \\
\hline PTSD $_{\text {lifetime }}$ & 141 & 159 & 34 & 73 & 43 & 107 & 43 & 34 & 116 \\
\hline PTSD $_{\text {current }}$ & 209 & 215 & 47 & 115 & 50 & 209 & 215 & 47 & 165 \\
\hline $\mathrm{P}_{\text {case-control-value }}$ & \multicolumn{2}{|c|}{0.722} & \multicolumn{3}{|c|}{0.642} & \multicolumn{2}{|c|}{0.384} & \multicolumn{2}{|c|}{0.423} \\
\hline
\end{tabular}

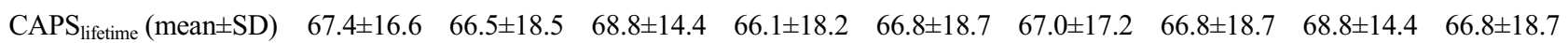

$\begin{array}{llllll}\mathrm{P}_{\text {CAPS-value }} & 0.668 & 0.771 & 0.971 & 0.489\end{array}$

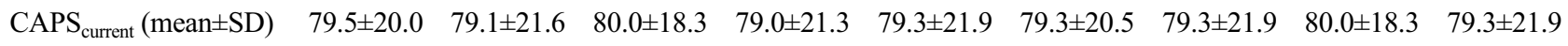

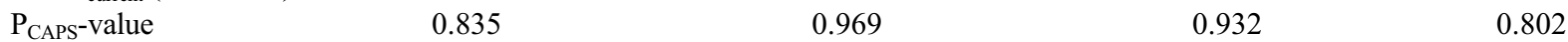

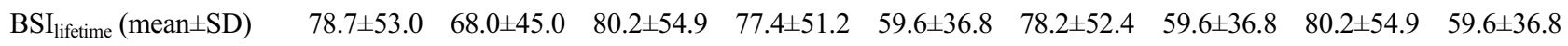

$\mathrm{P}_{\mathrm{BSI}}$-value

$0.089 \quad 0.031 \quad 0.305$

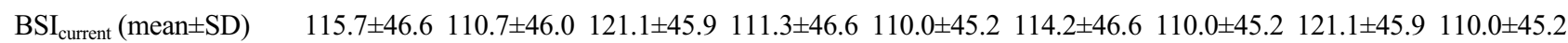
\begin{tabular}{lllll}
$\mathrm{P}_{\mathrm{BSI}}$-value & 0.262 & 0.418 & 0.618 & 0.189 \\
\hline
\end{tabular}

PTSD - posttraumatic stress disorder; CAPS - Clinician Administered PTSD Scale; BSI - Brief Symptom Inventory;

COMT - catechol-O-methyl-transferase; Italics indicates $p \leq 0.05$

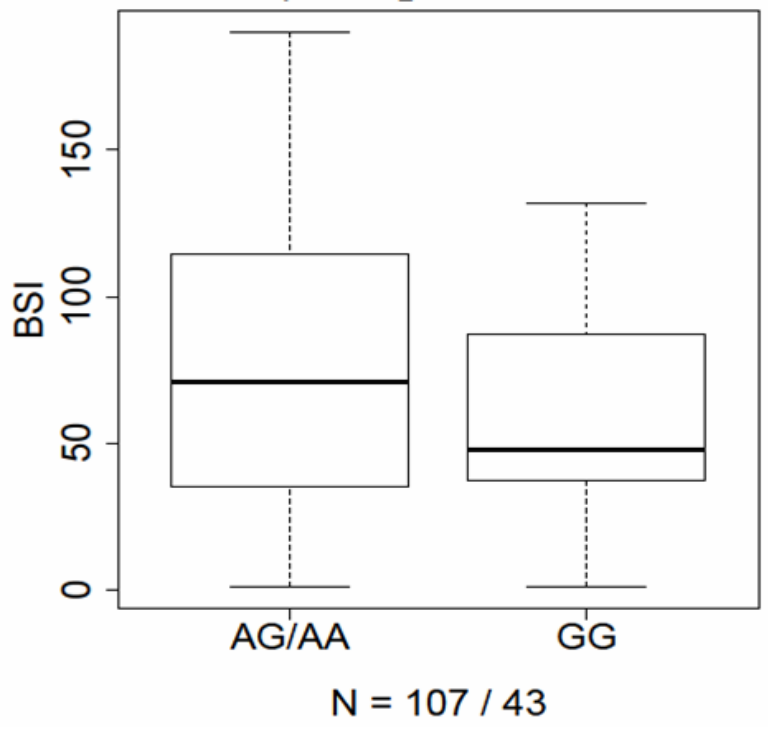

Figure 1. The distribution of the Brief Symptom Inventory (BSI) total score according to catechol-O-methyltransferase (COMT) genotypes in the dominant model $(\mathrm{P}=0.031)$ within the lifetime PTSD group

However, regression analyses on the BSI total score reached not in the current PTSD subgroup $\left(\mathrm{P}_{\mathrm{all}}>0.05\right)$, but in the lifetime PTSD group nominal significance in the dominant $(\mathrm{P}=0.031, \beta=19.34, \mathrm{SE}=8.88)$ (Table 1 and Figure 1) and allelic $(\mathrm{P}=0.047, \beta=11.46, \mathrm{SE}=5.72)$ (Table 1) model. These results indicate an association between the minor (A) allele and higher BSI scores (Table 1). However, none of the nominal associations withstood Bonferroni correction for multiple testing.

\section{Intereleukin6 gene}

The allele genotype distribution of the IL6 SNP rs1800795 in the PTSD group and controls are given in Table 2. No significant difference was found regarding IL6 SNP rs1800795 allele and genotype distributions between the PTSD group and controls $(\mathrm{P}>0.05)$. In contrast,

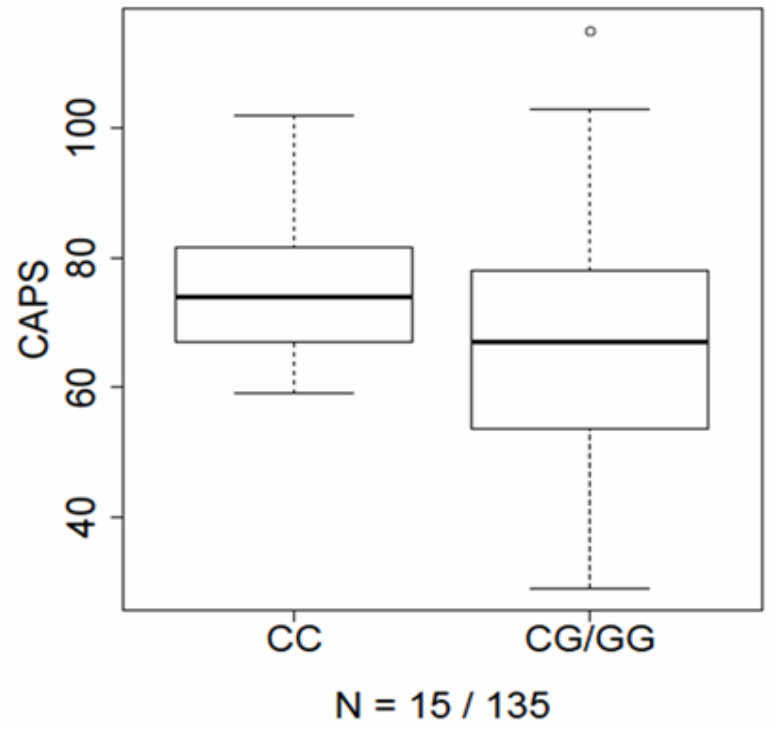

Figure 2. The distribution of the total score of posttraumatic stress disorder (CAPS) according to interleukin 6 genotypes in the recessive model $(\mathrm{P}=0.048)$ within the lifetime PTSD group

the recessive model predicting CAPS total score in the lifetime PTSD group was nominally significant $(\mathrm{P}=0.048$, $\beta=9.52, \mathrm{SE}=4.78)$ and indicated an association between the minor $(\mathrm{C})$ allele and higher CAPS scores (Table 2 and Figure 2). Also, the allelic $(\mathrm{P}=0.033, \beta=13.38, \mathrm{SE}=6.21)$, genotypic $(\mathrm{P}=0.028)$ and recessive $(\mathrm{P}=0.009, \beta=35.63$, $\mathrm{SE}=13.53$ ) (Figure 3 ) model predicting BSI total score in the lifetime PTSD group were nominally significant, each indicating again an association between the minor (C) allele and higher BSI scores (Table 2). This results could not be replicated within the current PTSD subgroup, where regression analysis reached in none of the calculated models any significance for the total CAPS and BSI scores $\left(\mathrm{P}_{\mathrm{all}}>0.05\right)$ (Table 2). None of the detected nominal significant associations remained significant after corretion for multiple tests. 
Table 2. Association results of IL6 rs1800795, along with genotype- and allele counts, for individuals in analysis, CAPS and BSI means and standard deviations (SD), as well as nominal P-values of regression analyses

\begin{tabular}{|c|c|c|c|c|c|c|c|c|}
\hline \multirow{2}{*}{ IL6 rs1800795 } & \multicolumn{2}{|c|}{ Allelic Model } & \multicolumn{3}{|c|}{ Genotypic Model } & \multicolumn{2}{|c|}{ Dominant Model } & Recessive Model \\
\hline & $\mathrm{C}$ & $\mathrm{G}$ & $\mathrm{CC}$ & $\mathrm{CG}$ & GG & $\mathrm{CC} / \mathrm{CG}$ & GG & $\mathrm{CG} / \mathrm{GG}$ \\
\hline Controls & 244 & 452 & 40 & 164 & 144 & 204 & 144 & 308 \\
\hline PTSD $_{\text {lifetime }}$ & 97 & 203 & 15 & 67 & 68 & 82 & 68 & 135 \\
\hline PTSD $_{\text {current }}$ & 152 & 282 & 21 & 110 & 86 & 131 & 86 & 196 \\
\hline$P_{\text {case-control-value }}$ & \multicolumn{2}{|c|}{0.643} & \multicolumn{3}{|c|}{0.765} & \multicolumn{2}{|c|}{0.875} & 0.465 \\
\hline $\mathrm{CAPS}_{\text {lifetime }}($ mean $\pm \mathrm{SD})$ & $69.3 \pm 17.0$ & $65.3 \pm 17.8$ & $75.5 \pm 11.0$ & $66.7 \pm 18.1$ & $63.2 \pm 17.1$ & $68.4 \pm 17.6$ & $63.2 \pm 17.1$ & $75.5 \pm 11.0 \quad 66.0 \pm 17.6$ \\
\hline $\mathrm{P}_{\mathrm{CAPS}-\text { value }}$ & \multicolumn{2}{|c|}{0.087} & \multicolumn{3}{|c|}{0.123} & \multicolumn{2}{|c|}{0.288} & 0.048 \\
\hline $\mathrm{CAPS}_{\text {current }}($ mean $\pm \mathrm{SD})$ & $78.9 \pm 20.6$ & $79.4 \pm 20.9$ & $78.9 \pm 20.4$ & $78.9 \pm 20.7$ & $79.8 \pm 21.0$ & $78.9 \pm 20.7$ & $79.8 \pm 21.0$ & $78.9 \pm 20.4 \quad 79.3 \pm 20.9$ \\
\hline $\mathrm{P}_{\text {CAPS-value }}$ & \multicolumn{2}{|c|}{0.734} & \multicolumn{3}{|c|}{0.931} & \multicolumn{2}{|c|}{0.705} & 0.919 \\
\hline $\mathrm{BSI}_{\text {lifetime }}($ mean $\pm \mathrm{SD})$ & $78.2 \pm 52.4$ & $70.2 \pm 46.9$ & $105.1 \pm 55.7$ & $71.1 \pm 48.3$ & $70.7 \pm 45.3$ & $74.5 \pm 50.8$ & $70.7 \pm 45.3$ & $105.1 \pm 55.7 \quad 70.0 \pm 47.4$ \\
\hline $\mathrm{P}_{\mathrm{BSI}}$-value & \multicolumn{2}{|c|}{0.033} & \multicolumn{3}{|c|}{0.028} & \multicolumn{2}{|c|}{0.214} & 0.009 \\
\hline $\mathrm{BSI}_{\text {current }}($ mean $\pm \mathrm{SD})$ & $112.4 \pm 44.8$ & $112.9 \pm 46.9$ & $123.0 \pm 42.3$ & $108.3 \pm 45.1$ & $115.9 \pm 47.8$ & $110.7 \pm 45.0$ & $115.9 \pm 47.8$ & $123.0 \pm 42.3 \quad 111.6 \pm 46.4$ \\
\hline $\mathrm{P}_{\mathrm{BSI}^{-} \text {-value }}$ & \multicolumn{2}{|c|}{0.821} & \multicolumn{3}{|c|}{0.263} & \multicolumn{2}{|c|}{0.349} & 0.299 \\
\hline
\end{tabular}

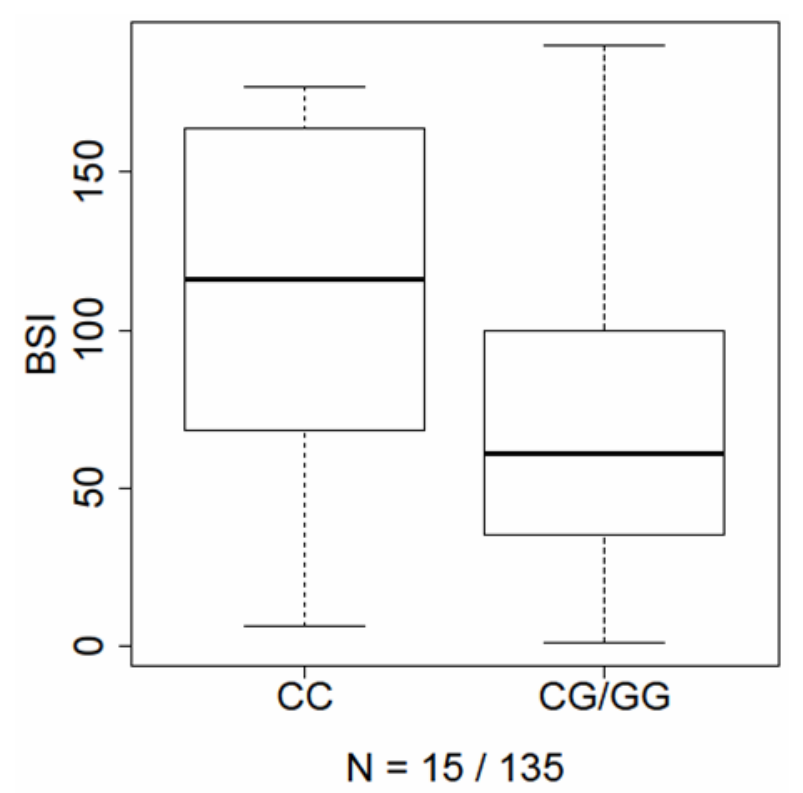

Figure 3. The distribution of the Brief Symptom Inventory (BSI) total values according to interleukin 6 genotypes in the recessive model $(\mathrm{P}=0.009)$ within the lifetime PTSD group

\section{DISCUSSION}

Many ongoing analyses are trying to identify novel gene candidates through genome-wide association studies (GWAS) and other powerful genomic approaches in PTSD. Although our goal is to understand the COMT and IL6 gene pathways that are associated with PTSD, this study examined particularly how those genes act on the development of the disorder and the severity of psychopathological symptoms. In our study there was no significant difference between the PTSD group and controls in genotype distributions of the COMT gene. The results of the regression analyses for the total CAPS scores were not significant in allelic and dominant models for the current and lifetime PTSD patient subgroups. However, our results suggest an association of the minor (A) allele of rs4680 and elevated BSI scores in patients with remitted/lifetime PTSD. A significant association between one or more copies of the Met158 allele and PTSD has been reported (Valente et al. 2011), and in addition a geneenvironment interaction between the Met158 allele and the number of traumatic event types in predicting PTSD (Kolassa et al. 2010). While our results do not show an association of the polymorphism with PTSD itself, they are consistent with the results of the study of Norrholm et al. (2013) who examined the intermediate phenotype of fear inhibition in PTSD and they found that individuals with Met/Met genotype demonstrated impaired fear inhibition, which may be mediated by higher methylation in the COMT promoter region. It means that regulation of COMT and subsequent catecholamine neurotransmitter cascades may be an important factor in fear processing for patients with PTSD. Despite the strong influence of genotype on COMT activity, the relationship between the Val158Met polymorphism and behavior, psychiatric disorders, and cognition has been found to be moderate and inconsistent (Baekken et al. 2008, Barnett et al. 2008). The low-activity Met allele has been associated with higher incidence of major depression (Ohara et al. 1998a) and with reduced generalized anxiety across adolescence (Olsson et al. 2007). No significant association of COMT genotypes and anxiety disorder was found in the study of Ohara et al. (1998b), but several studies are in line with our study where the association of COMT gene polymorphisms with anxiety was found (Benjamin et al. 2000, Kolassa et al. 2010, Hettema et al. 2006). Lonsdorf et al. (2010) found that Val carriers (Val/Val or Val/Met) endorsed more anxiety and depressive symptoms than Met homozygotes, which correlates with the findings in our study. The Val 
allele has been associated with higher level of phobic anxiety (McGrath et al. 2004), but other studies indicate the Met allele is associated with anxiety traits (Eley et al. 2003, Hoth et al. 2006). Some studies have identified sex differences in COMT activity. A metaanalysis of twenty seven studies found a sex specific association across anxiety traits, such that Val-carriers had higher anxiety scores than Met homozygotes only among males (Lee \& Prescott 2014). An association of panic disorder with the Val158 allele in women has been reported (Domschke et al. 2004).

There is growing evidence of a relationship between inflammatory markers, such as IL6 and PTSD. Some studies found a positive relationship between IL6 and PTSD (Maes et al. 1999). But the question is whether IL6 is elevated only at the onset of PTSD symptomatology, or the inflammation is related to the specific key components that define PTSD. In our study a nominally significant difference was found between the genotypes of the IL6 SNP rs1800795 regarding the total CAPS and total BSI scores, in the group of patients with lifetime PTSD. In fact, homozygous $\mathrm{C}$ allele carriers had higher CAPS and BSI scores results than heterozygous individuals and homozygous $\mathrm{G}$ allele carriers.

Studies investigating inflammatory markers in PTSD have yielded controversial results. It is well known that the levels of inflammatory markers depend on the severity and duration of illness, the presence of comorbid major depressive disorders, and the use of psychotropic medication. IL6 levels remained increased in the PTSD group and were positively associated with a severity of illness. For most inflammatory markers, study heterogeneity was reported to be high. Ekdahl et al. (2003) in his study reported that inflammation is implicated in the etiology and pathophysiology of several brain pathologies such as: major depression, Alzheimer's disease, and post-stroke depression. We have also found that in the recessive model for the minor allele (C), a significant result was obtained for total CAPS and for BSI. Also some authors suggest that small-study effects may contribute to an over estimation of the association between PTSD and IL6, (Maes et al. 1999), but because the sample composition was highly correlated with depression and medication status, it is hard to tell if medication, comorbid major depressive disorder, or research bias truly predicts the observed effect size. Future genetic studies in various psychiatric disorder such as PTSD, depression or psychosis might explore more of the dual role of the IL6 gene in health and disease states.

Some limitations of this study are the heterogenity of the PTSD and control group with regard to different population origins (countries) and type and duration of trauma (war). It may also be that the small groups of patients, when separated into lifetime PTSD and current PTSD reduce the statistical power.

\section{CONCLUSIONS}

In conclusion, results from this study support the notion that the Val158Met COMT polymorphism as well as interleukin-6 genetic variation contribute to the genetic susceptibility to PTSD. Identification of PTSD biological pathways strengthens the hope of progress in the mechanistic understanding of a model psychiatric disorder and allows for the development of targeted treatments and interventions (Lynn et al. 2014).

\section{Acknowledgements:}

We thank all the participants and their families without whose idealistic and enthusiastic support the study would not have been possible. We also would like to thank at Sarajevo: the Association of Women Victims of War and Bakira Hasecic, the Association of Physically Handicapped, Zilko Buljugija, Zoran Budimlija, MD, PhD, Jasminka Krehic, MD, PhD, Elvira Sabanovic, RSN and Subhija Gusic; in Kosovo: Feride Rushiti, MD, Selvije Izeti, MSc, Vjosa Devaja, MD, Melita Kallaba, MD from Kosova Rehabilitation Center for Trauma Survivors- KRCT; Emirjeta Kumnova, Veprore Shehu from Medica Kosova; Zahrije Podrimqaku Subashi from the Association of Political Prisoners, Kadire Tahiraj from the Center for Promotion of Women's Rights; Arbërore Ulaj, MD, Teuta Haxhiu, MD and Drita Gashi, MD, for their assistance in recruiting and interviewing participants; at Zagreb: Mirica Mavracic, Zoran Bradas, Zrinka Mirkovic and Maja Mezak Herceg for technical assistance in drawing blood and extracting DNA; at Tuzla: the staff of the Department of Transfusion of University Clinical Center of Tuzla, and the staff of the Department of Psychiatry, in particular Emina Hujdur, Medin Omerašević and Avdo Šakušić, MD for technical support and Maja Brkić and Sandra Zornić for their assistance in data collection; at Würzburg: Carola Gagel for technical assistance with extracting DNA. Thanks are highly deserved by and gratefully extended to Peter Riederer as spiritus rector who brought the consortium together. The study was funded by the DAAD program Stability Pact for South Eastern Europe and supported by the DFG-funded RTG 1253 (speaker Pauli) as well as the DFG-funded CRC-TRR58 (projects C02 Domschke, Deckert, and Z02 Deckert, Domschke).

Conflict of interest: None to declare.

\section{Contribution of individual authors:}

Each author has actively participated in the international research project (see Acknowledgments) and, therefore, has substantially contributed to the development and publication of this manuscript.

\section{References}

1. Agani F, Landau $J$ \& Agani N: Community-building before, during, and after times of trauma: the application of the LINC model of community resilience in Kosovo. Am J Orthopsychiatry 2010; 80:143-149

2. American Psychiatric Association: Diagnostic and Statistical Manual of Mental Disorders. 4th Edition revised. American Psychiatric Association, Washington DC, 2000

3. Arcel LT \& Ljubtina D: Assessment of psycho-social status and treatment of refugee women and their families. 114-117. Nakladnistvo Lumin Zagreb, 1995 
4. Baekken PM, Skorpen F, Stordal E, Zwart J.A \& Hagen $K$ : Depression and anxiety in relation to catechol-Omethyltransferase Val158Met genotype in the general population: The Nord-Trondelag Health Study HUND. BMC Psychiatry 2008; 8:48

5. Baker DG, Ekhator NN, Kasckow JW, Hill KK, Zoumakis E, Dashevsky BA et al.: Plasma andcerebrospinal fluid interleukin-6 concentrations in posttraumatic stress disorder. Neuroimmunomodulation 2001; 9:209-217

6. Barnett JH, Scoriels L \& Munafo MR: Meta-analysis ofthe cognitive effects of the catechol-O-methyltransferase gene Val158/108Met polymorphism. Biol Psychiatry 2008; 64:137-144

7. Benjamin J, Osher Y, Kotler M, Gritsenko I, Nemanov L, Belmaker RH et al: Association between tridimensional personality questionnaire (TPQ) traits and three functional polymorphisms: dopamine receptor D4 (DRD4), serotonin transporter promoter regions (5-HTTLPR) and catechol-Omethyltransferase. Mol Psychiatry 2000; 5:96-100

8. Blake DD, Weathers FW, Nagy LM, Kaloupek DG, Gusman $F D$, Charney DS et al.: The development of a clinicianadministered PTSD scale. J Trauma Stress 1995; 8:75-90

9. Borovikova LV, Ivanova S, Zhang M, Yang H, Botchkina GI, Watkins LR et al.: Vagus nerve stimulation attenuates the systemic inflammatory response to endotoxin. Nature 2000; 405:458-462

10. Boscarino JA, Erlich PM, Hoffman SN, Rukstalis $M$ \& Stewart WF: Association of FKBP5, COMT and CHRNA5 polymorphisms with PTSD among outpatients at risk for PTSD. Psychiatry Res 2011; 188:173-4

11. Broekman BFP, Olff $M \&$ Boer F: The genetic background to PTSD. Neurosci Biobehav Rev 2007; 31:348-362

12. Carpenter L, Gawuga C, Tyrka A, Lee J, Anderson G \& Price L: Association between plasma IL-6 response to acute stress nad early-life adversity in healthy adults. Neuropsychopharmacology 2010; 35:2617-2623

13. Derogatis L \& Melisaratos N: The Brief Symptom Inventory: An introductory report. Psychol Med 1983; 13:595-605

14. Deverman BE \& Patterson PH: Cytokines and CNS development. Neuron 2009; 64:61-78

15. Domschke K, Freitag CM, Kuhlenbaumer G, Schirmacher A, Sand P, Nyhuis $P$ et al.: Association of the functional V158M catechol-O-methyl-transferase polymorphism with panic disorder in women. Int $J$ Neuropsychopharmacol 2004; 7:183-188

16. Džubur Kulenović A, Agani F, Avdibegović E, Jakovljević M, Babić D, Kučukalić A et al.: Molecular Mechanisms of Posttraumatic Stress Disorder (PTSD) as a Basis for Individualized and Personalized Therapy: Rationale, Design and Methods of the South Eastern Europe (SEE)PTSD study. Psychiatr Danub 2016; 28:154-163

17. Egan MF, Goldberg TE, Kolachana BS, Callicott JH, Mazzanti CM, Straub RE et al.: Effect of COMT Val108/ 158Met genotype on frontal lobe function and risk for schizophrenia. Proc Natl Acad Sci USA 2001; 98:6917-6922

18. Ehlis AC, Reif A, Herrmann MJ, Lesch KP \& Fallgatter $A J$ : Impact of catechol-O-methyltransferase on prefrontal brain functioning in schizophrenia spectrum disorders. Neuropsychopharmacology 2007; 32:162.170

19. Ekdahl CT, Claasen JH, Bonde S, Kokaia Z \& Lindvall O: Inflammation is detrimental for neurogenesis in adult brain. Proc Natl Acad Sci USA 2003; 100:13632-7
20. Eley TC, Tahir E, Angleitner A, Harriss K, McClay J, Plomin $R$ et al.: Association analysis of MAOA and COMT with neuroticism assessed by peers. Am J Med Genet Neuropsychiatr Genet 2003; 120B:90-96

21. Erta M, Quiantana J \& Hidalgo J: Interleukin-6, a Major Cytokine in the Central Nervous System. Int J Biol Sci 2012; 8:1254-66

22. Gillespie CF, Phifer J, Bradley B \& Ressler KJ: Risk and resilience: Genetic and environmental influences on development of the stress response. Depress Anxiety 2009; 26:984-992

23. Grossman MH, Emanuel BS \& Budarf ML: Chromosomal mapping of the human catechol-O-methyltransferase gene to $22 q 11.1$ 22q11.2.Genomics 1992; 12:822-825

24. Hasko $G$ \& Szabo C: Regulation of cytokine and chemokine production by transmitters and co-transmitters of the autonomic nervous system. Biochem Pharmacol 1998; 56:1079-1087

25. Hettema JM, Neale MC, Myers JM, Prescott CA \& Kendler KS: A population-based twin study of the relationship between neuroticism and internalizing disorders. Am J Psychiatry 2006; 163:857-864

26. Hoth KF, Paul RH, Williams LM, Dobson-Stone C, Todd E, Schofield PR et al.: Associations between the COMT Val/ Met polymorphism, early life stress, and personality among healthy adults. Neuropsychiatr Dis Treat 2006; 2:219-225

27. Kasai K, Yamasue H, Gilbertson MW, Shenton ME, Rauch $S L$ \& Pitman RK: Evidence for acquired pregenual anterior cingulate gray matter loss from a twin study of combat-related posttraumatic stress disorder. Biol Psychiatry 2008; 63:550-556

28. Kishimoto T, Akira S, Narazaki M\& Taga T: Interleukin-6 family of cytokines and gp130. Blood 1995; 86:1243-1254

29. Koenen KC: Genetics of posttraumatic stress disorder: review and recommendations for future studies. J Trauma Stress 2007; 20:737-750

30. Kolassa IT, Kolassa S, Ertl V et al.: The risk of posttraumatic stress disorder after trauma depends on traumatic load and the catechol-O-methyltransferase Val $158 \mathrm{Met}$ polymorphism. Biol Psychiatry 2010; 67:304-308

31. Lee LO \& Prescott CA: Association of the Catechol-OMethyltransferase (COMT) Val158Met Polymorphism and Anxiety-Related Traits: A Meta Analysis. Psychiatr Genet 2014; 24:52-69

32. Lonsdorf TB, Rück C, Bergströnm J, Andersson G, Öhman A \& Lindefors $N$ : The COMTval158met polymorphisms is associated with symptom relief during exposure-based cognitive-behavioral treatment in panic disorder. BMC Psychiatry 2010; 10:99-107

33. Lopes B, Kaiser R, Gotway CA \& Agani F: Mental Health, Social Functioning, and Feelings of Hatred and Revenge of Kosovar Albanians one Year After the War in Kosovo. $J$ Trauma Stress 2003; 16:351-360

34. Lynn M, Negar F, Alicia K \& Kerry J: Genetic approaches to understanding post-traumatic stress disorder. Int J Neuropsychopharmacol 2014; 17:355-370

35. MacQueen GM \& Frodl T: The hippocampus in major depression: Evidence for the convergence of the bench and bedside in psychiatric research? Mol Psychiatry 2010; 16:252-264

36. Maes M, Lin AH, Delmeire $L$ et al.: Elevated serum interleukin-6 (IL-6) and IL-6 receptor concentrations in 
posttraumatic stress disorder following accidental manmade traumatic events. Biol Psychiatry 1999; 45:833-839

37. Maes M, Lin AH, Delmeire L, Van Gastel A, Kenis G, De Jongh $R$ et al.: Elevated serum interleukin-6 (IL-6) and IL6 receptor concentrations in posttraumatic stress disorder following accidental man-made traumatic events. Biol Psychiatry 1999; 45:833-9

38. Malhotra AK, Kestler LJ, Mazzanti C, Bates JA, Goldberg $T$ \& Goldman D: A functional polymorphism inthe COMT gene and performance on a test of prefrontal cognition. Am J Psychiatry 2002; 159:652-654

39. McGrath M, Kawachi I, Ascherio A, Colditz GA, Hunter $D J$ \& De Vivo I: Association between catechol-Omethyltransferase and phobic anxiety. Am J Psychiatry 2004; 161:1703-1705

40. Neuner F, Schauer M, Karunakara U, Klaschik C, Robert $C \&$ Elbert T: Psychological trauma and evidence for enhanced vulnerability for posttraumatic stress disorder through previous trauma among West Nile refugees. BMC Psychiatry 2004; 4:34

41. Norrholm SD, Jovanović T, Smith AK et al.: Differential genetic and epigenetic regulation of catechol-O-methyltransferase is associated with impaired fear inhibition in posttraumatic stress disorder. Front Behav Neurosci 2013; 7:30

42. Ohara K, Nagai $M$ \& Suzuki Y: Low activity allele of catechol-O-methyltransferasegene and Japanese unipolar depression. Neuroreport 1998a; 9:1305-1308

43. Ohara K, Nagai M, Suzuki Y, Ochiai M \& Ohara K: No association between anxiety disorders and catechol-Omethyltransferase polymorphism. Psychiatry Res 1998b; 80:145-148

44. Olsson CA, Byrnes GB, Anney RJ, Collins V, Hemphill SA, Williamson $R$ et al.: COMT Val(158)Met and 5HTTLPR functional loci interact to predict persistence of anxiety across adolescence: Results from the Victorian adolescent health cohort study. Genes Brain Behav 2007; 6:647-652

45. Passos IC, Vasconcelos-Moreno MP, Costa LG et al.: Inflammatory markers in post-traumatic stress disorder: a systematic review, meta-analysis, and meta-regression. Lancet Psychiatry 2015; 2:1002-1012

46. Pooley EC, Fineberg $N \&$ Harrison P: The met 158 allele of catechol-O-methyltransferase (COMT) is associated with obsessive-compulsive disorder in men: case-control study and meta-analysis. Mol Psychiatry 2007; 12:556-561

47. Priebe S, Bogić M, Ajduković D, Frančišković T, Galeazzi GM, Kučukalić A et al: Mental disorders following war in the Balkans: a study in 5 countries. Arch Gen Psychiatry 2010; 67: 518-528

48. Quintana A, Müller M, Frausto RF, Ramos R, Getts DR, Sanz E et al.: Site-specific production of IL6 in the central nervous system retargets and enhances the inflammatory response in experimental autoimmune encephalomyelitis. J Immunol 2009; 183:2079-2088

49. Rohleder N, Joksimović L, Wolf JM \& Kirschbaum C: Hypocortisolism and increased glucocorticoid sensitivity of pro-Inflammatory cytokine production in Bosnian war refugees with posttraumatic stress disorder. Biol Psychiatry 2004; 55:745-751

50. Valente NL, Vallada H, Cordeiro Q, Bressan RA, Andreoli $S B$, Mari JJ et al.: Catechol-O-methyltransferase (COMT) val158met polymorphism as a risk factor for PTSD after urban violence. J Mol Neurosci 2011; 43:516-523

51. Whitney NP, Eidem TM, Peng H, Huang $Y$ \& Zheng JC: Inflammation mediates varying effects in neurogenesis: relevance to the pathogenesis of brain injury and neurodegenerativedisorders. J Neurochem 2009; 108:1343-1359

Correspondence:

Shpend Haxhibeqiri, MD

Institute of Kosovo Forensic Psychiatry, University Clinical Centre of Kosovo

Forenzika p.n. 10000 Prishtine, Republika e Kosoves

E-mail: dr.shpendhaxhibeqiri@gmail.com 